\title{
Impact of Relationship Marketing on the Performance of Service Companies: An Empirical Study on NCR
}

\author{
Dr. Tushar Kanti, Ms. Shivani Dixit, \\ Executive Director, IME Ghaziabad \\ Research Scholar, Mewar University,
}

\begin{abstract}
Today's customers buying decisions are not based simply on the quality of the product but with the relationship they have with the company. So organizations will have to formulate marketing strategies in a way to not only woo customers toward them but also to retain them. The objective of the study therefore was to empirically investigate the effect of Relationship Marketing $(R M)$ on the performance of service companies. This paper provides a comprehensive review on this concept of RM in the service sector, its foundation as well as its development.The type of research used for this study is descriptive research design. A well structured questionnaire was designed for service providers and administered to collect samples across NCR. Due to high population and need for variety of respondents, Convenience Sampling method was chosen. Data were collected from a cross-section of customers (consisting of 100 samples). Furthermore the paper provides a discussion on the nature and scope of RM and proposes some recommendations to assist firms in the implementation of this new marketing concept. The findings revealed that there are several measures of RM i.e. service quality, trust, price perceptions, complaint handling and customer satisfaction which are responsible for the performance of service companies like Telecom, Healthcare, Banking, Insurance, and Entertainment and so on. Finally the concluding note of this study reflects that the RM and service delivery are the factors responsible for the performance and the growth of service companies.
\end{abstract}

Keywords: Relationship Marketing, Service Companies, Customer Satisfaction, Complaint Handling, Price Perceptions.

\section{Introduction}

"As our economy becomes more service and technology oriented, the dynamics of the sales process will change. The on-going nature of services and the growing complexity of technology will increasingly necessitate lengthy and involved relationships between buyers and sellers. Thus, the seller's focus will need to shift from simply landing sales to ensuring buyer satisfaction after the purchase. To keep buyers happy, vendors must maintain constructive interaction with purchasers - which includes keeping up on their complaints and future needs. Repeat orders will go to those sellers who have done the best job or nurturing these relationships..." Information gathered through communication with customers can enable organizations to develop a marketing mix that is more likely to create customer satisfaction. With the increase in the competition organizations realize that what customer's value, is not always just lower prices, but also aspects such as delivery, image and brand associations, the link with customers becomes increasingly important. When the market growth slows down or as the markets become more competitive, firms are more likely to attempt to maintain their market share by focusing on retaining the current customers. (Lee et al., 2001).

Customer Relationship Management (CRM) Service is a marketing strategy that ensures the acquisition and retention of most profitable customers using the most effective method. Thus, tremendous growth of services sector implies the role of marketing in terms of vast opportunities and implications, marketing opportunities arising from new technology, in franchising from fewer regulations and professional restrictions, in servicing physical goods and international markets (Lovelock, 1999). The rapid growth of services industry has changed the conditions of business. Customer retention has been advocated as an easier and more reliable source of superior performance (Reichheld and Sasser, 1990). It has now become common knowledge that the value of all customers is not same, the $80 / 20$ rule prevails whereby we have learned that 20 percent of customers generate more than 80 percent of revenues for most companies, and it is not uncommon to find that an even lower percentage of customers can generate more than 80 to 90 percent of the revenues. Under such circumstances, it is not prudent for a company to allocate equal resources to all customers. Customer segmentation and program differentiation is needed in order to match revenue potential with service offerings. Those with higher revenue potential deserve a greater allocation of costs and service. Otherwise, competitors will seize the opportunity by offering better service and a greater allocation of resources for the high-end customers. At the lower-end, attempts should be made to achieve cost savings through the reallocation of efforts based on less-expensive resources. This can be done with the help of RM strategy. It is based on the idea that the happier a customer is with a relationship, the greater the likelihood that they will stay with an organization. 
Research has shown that the cost of attracting a new customer is estimated to be five times the cost of keeping a current customer happy (Jackson1985:23, Ndubisi et al., 2009, Ndubisi, 2003, Reichheld et al., 2000). The ultimate aim of a RM approach is for the customer to become a 'partner' of the organization, by contributing to marketing decisions through a one-to-one relationship.

\section{Literature Review}

The concept of RM emerged as an opponent to traditional marketing theories since early 1990s, when the paradigm shifted from transactional to relational marketing. It is a strategy used to learn more about customer's mood and behaviors in order to develop stronger relationship with them. The new paradigm asserts that intelligent marketers should view existing customers as a tremendous growth opportunity (Cindy Claycomb $\backslash$ and Charles L. Martin 2002).It can be used to build a loyal customer base and as a result the brands marketed by the company will grow in strength by leaps and bounds. Marketers realize that a long lasting relationship is more profitable than a onetime transaction. Since that, RM had received an increasing amount of attention in marketing research (Gronroos, 1994; 1999), especially in the service industry. Apart from that, the reality of many services being consumed in an ongoing or periodic basis such as insurance and telecommunication (Lovelock, 1983), coupled with the reality of customers forming relationship with people rather than goods paves the way for RM. In fact, repeat interaction between customers and service providers offered wide opportunity for relationship marketing to exist (Wong and Sohal, 2002). Even when membership is not required, customers may ask for on-going relationships with the service providers to reduce their perceived risk in evaluating services. Nonetheless, it is vital to know that RM is not applicable to every service situations, as emphasized by Barnes (2002).

For academicians it is a paradigm shift in marketing philosophy urging the importance of long term relationship and retaining existing customers over getting new customers; since a bird in hand is better than the two in a bush. For practitioners RM is a competitive advantage (Day, 2000), a tool to reduce the customer churn (Schneider and Bowen, 1999), a tool to overcome service failures (Crosby and Stephens, 1987), an opportunity for marketing additional products and services to a more receptive customer base (Priluck, 2003) Shani and Chalasani (1992) view RM as an integrated effort to identify, maintain, and build up a network with individual consumers and to continuously improve the network for the benefits of all stakeholders, through interactive, personalised, and value-added contacts over a long period of time. Its application is most relevant to a service based company when each of the following conditions are fulfilled: 1) the customer must has an ongoing or periodic desire for the service (e.g., telephone versus funeral home service); (2) the service customer must control the selection of the supplier (e.g., selecting a dry cleaner versus entering the first taxi in the airport waiting line); and (3) there must be alternate suppliers (e.g., patronizing various restaurants versus buying electricity from the one electric utility serving a community). Similarly, Berry (1983) also suggested that the three conditions above should exist in an attempt for RM to be useful.

\section{Origin of Relationship Marketing}

Relationship Marketing emerged in the 1980's as an alternative to the prevailing view of marketing as a series of transactions, because it was recognized that many exchanges, particularly in the service industry, were relational by nature (Berry, 1983; Dwyer et al., 1987; Grönroos, 1994; Gummesson, 1994; Sheth and Parvatiyar, 2000). It aims at increasing customer profitability while providing better services for customers. Several studies have empirically demonstrated a positive association between RM strategies and business performance (e.g. Naidu et al., 1999; Palmatier and Gopalakrishna, 2005).

In 1983 Leonard L. Berry, distinguished professor of Marketing at Texas A\&M University, coined the word Relationship Marketing when he presented a paper entitled "Relationship Marketing at the American Marketing Association's" Services Marketing Conference. The paper was published in the conference proceedings and for the first time the phrase RM appeared in the Marketing literature. Later Jackson (1985) used the concept in Business to Business context.Another opinion is that it is a gradual extension of "the Nordic School"approach to services marketing and management (Gummesson, 1997). There are ample examples to prove that long-term relationship emphasized by the Nordic School researchers (Grönroos,2000) but without using the term RM as early as 1977, before Berry and BundJackson used the term RM.The idea of developing and fostering relationship with customers is not something revolutionarily new, but many firms are realizing its significance for the first time.This phenomenon is as old as the history of trade and commerce (Grönroos, C.2004). So, we can say that it is a new-old concept (Berry 1995).Even if the concept is rather recent within the science of marketing, we must admit that the values it represents are far from new. It seems to be the theorization and modernization of a latent secular process present in the industrialized world. In fact, marketing has always been and still remains a science of exchange which aims to analyse and understand the relationship between supplies (seller) and demand (buyer). The meeting of supply and demand of products and services involves a rather complex subject often called 'business' - an umbrella term which covers all major areas of 
management such as marketing, finance, production, accounting, information systems, organizational structures, and even human resources. Creating 'relationships' within business is one of the oldest jobs in the world which always required exchanges.

Traditionally Preference was judged on the basis of face-to-face contact and, from this, trust was developed; through personal knowledge and trust, a supplier was also able to judge the creditworthiness of each customer (Palmer, 1995). But now days Consumers shifted their liking from the personal characteristics of the producer to the abstract concept of the brand. Branding emerged as a means of providing reassurance of consistent quality to spatially dispersed customers who, because of the use of intermediaries, had no direct relationship with the manufacturers of their products. In effect, brand became a substitute for personal relationship (Palmer, 1997).

One of the earliest notions of RM in the academic sphere can be traced to Levy and Zaltman's (1975) statement that to maximize the value of exchanges, people or groups need to develop 'patterned relationships with one another.' But, although the origins of RM were initially in the industrial context (with the network approach as designed by the Industrial Marketing and Purchasing (IMP) Group, e.g., Häkansson and Snehota,1995), the service industry has increasingly become focused on maintaining and enhancing customer relationships. Most sources credit Berry (1983) with originating the term RM. Houston and Gassenheimer (1987) argued that if attention is limited to the study of single, isolated exchanges, then the heart of marketing is ignored. Other scholars state that developing relationships has now become the focal point for marketing attention replacing earlier preoccupations with service and product development (Christopher, Payne and Ballantyne, 1991). Webster (1992) argued that the relationship marketing paradigm promises to redefine marketing practice and the role of marketing in the firm. Adopting a RM approach involves changing the traditional ways of managing marketing at the strategic and tactical level (Gronröos, 1996). Three important strategic issues in the RM approach can be distinguished:

- redefining the business as a service business and the key competitive element as service competition

- looking at the organization from a process management perspective and not from a functional perspective

- establishing partnerships and a network to be able to handle the whole service process.

At the tactical level, there are three typical elements:

- seeking direct contact with customers and other stakeholders

- building a database covering necessary information about customers and others

-developing a customer-oriented service system.

\section{Relationship Marketing in Service Industry}

In service industry particularly in ICT industry such strategies play a very critical role in enhancing retention. Attraction of new customers is an intermediate step in marketing process. Solidifying relationship and transforming them as loyal customers, serving customers as clients too should be a part of marketing (Berry, 1983). Authors such as Don Peppers and Martha Rogers discuss the transition from managing products to managing customers, and differentiating customers rather than just products. This transition allows companies to develop economies of scope rather than economies of scale. To retain their customer base and satisfy customer requirements above those of competitors, brands must engage in the following process:

- Identify potential customers.

- Determine their needs and lifetime value to the company.

- Interact with customers and gather data on their requirements and behavior patterns.

- Customize products, services, and communications to individual customers.

Implementing these practices helps companies counterbalance new customers and opportunities with current and existing customers to maximize profit. It also counteracts the theory that new customers must be gained at the expense of losing older ones. Many companies in competing markets will redirect or allocate large amounts of resources toward customer retention, particularly in markets with increasing competition. Lead generation activities geared towards attracting new customers may be more expensive than the money and time spent on promotional tactics to retain existing customers. To end up this literature review it is to be noted that, business is meant to generate value to all shareholders. In that, whilst serving the customer and establish long term relationship, this should be done only up to the extent that customer retention delivers value for shareholders. Therefore it is essential that answer is found for the question "Does customer satisfaction and retention lead to profitability?"

\section{The link between Loyalty (or Customer Retention) and profitability}

Numerous studies have shown positive links between loyalty and firm profitability (Anderson et al., 1994; Hallowell, 1996; Reichheld, 1996; Silvestro and Cross, 2000). Nonetheless, not all loyal customers are profitable (Storbacka, 1994; 1997). According to Reinartz and Kumar (2002), the overall link between loyalty and profitability in many industries is questionable for two reasons: 1) a relatively large percentage of long-term 
customers are only marginally profitable, and 2) a relatively large percentage of short-term customers are highly profitable. It is noteworthy, however, that Reinartz and Kumar's (2002) findings from four industries (high technology, postal service, retail food and direct brokerage) still indicate that a larger proportion of the longterm customers than of the short-term customers exhibit high profitability, and a larger proportion of the highprofitability customers than of the low-profitability customers are long-term customers. Thus, the theory of an overall positive connection between customer loyalty and profitability cannot be rejected. As noted by Anderson and Mittal (2000), customer relationship profitability arises through the acquisition and retention of "high quality" customers with low maintenance costs and high revenue.

\section{Objective}

The problem definition of this study is to examine whether the practice of RM influences the performance of service organizations. The study is based on the information gathered and collected from both primary and secondary sources. The sample for the study is made from the employees of service companies from NCR. Data analysis for the study was done using frequencies and percentages.

1) To assess the awareness of the concept of RM among service companies and how far this technique helps in securing a competitive edge.

2) To examine whether the practice of RM influences the performance of service organizations.

3) To study the benefits of RM which accrue to both the customers and the organizations

\section{Methodology}

In the early stages of the research, there was a lack of sufficient understanding of the problem of RM. An exploratory study was conducted to clarify concepts and techniques of RM among service companies. Experience surveys were also held to tap the knowledge and experience of companies in NCR which are familiar with the concepts of RM. Structured undisguised questionnaire were used to collect data.The questions were presented exactly the same wording and the same order to all the service companies when collecting data.Questionnaires were distributed to the customers and have been asked to contact the researcher whenever they encounter any difficulty in responding to the questionnaire. Convenience sampling is used in this study where the researcher is interested in getting an inexpensive approximation of the truth. A population is made up of all conceivable elements, subjects or observations relating to a particular phenomenon of interest to the researcher. Data was collected using the "Personal contact" after approaching the respondents personally and explaining in detail about the survey objectives and purpose of the study.

\section{Analysis And Discussions}

The data collected from the primary source has been tabulated and this forms the major basis for the research study.

For the purpose of data analysis, simple descriptive analysis and percentages were used. Table 1 reveals that out of the 100 respondents, $44 \%$ were from Telecom, $6 \%$ from banking, 3\% from Insurance, $10 \%$ from education, $7 \%$ from tourism, $2 \%$ from Entertainment, and $18 \%$ from healthcare. Data analysis reveals that over $68 \%$ of the respondents are male compare to their female counterpart. In the same vein, $55 \%$ unveiled the fact that majority of respondents are from the age group of 25-30 years. Education makes a difference in articulation of opinions. The academic qualification shows that around $38 \%$ of the respondents are graduate, $33 \%$ are post graduate, $26 \%$ have professional qualification and rest $3 \%$ have passed senior secondary. The research study also reveals that about $81 \%$ of the respondents have spent between 4 years $\&$ above in the service industry, while $12 \%$ have spent $1-4$ years, $4 \%$ spent $6 \mathrm{~m}-1$ year and $3 \%$ have spent around 6 months and below.

Initially the main focus was on basic understanding of the concept of RM among service companies. And it was interesting to note that most of the Companies were aware of the notion of 'relationship marketing' and was striving hard towards implementing this new concept to build lasting relationships with their customers. It plays a major role in service performance and customer retention. It was encouraging sign that $27 \%$ of the respondents felt that it plays a very crucial role for the service performance, while maximum percentage i.e. $57 \%$ of the service providers have a belief that RM plays an important role for the service performance (Source: Table-2).

Knowing the customers again a very important factor for the growth and retention. Table 3 reveals that only $43 \%$ of the service providers are having very good customer information on their database, $39 \%$ moderately know their customers, rest $15 \%$ concerned for the present transaction and $3 \%$ are unfamiliar with customer information.

Service design is the activity of planning and organizing people, infrastructure, communication and material components of a service in order to improve its quality and the interaction between service provider and customers. Its purpose is to design according to the needs of customers or participants, so that the service is user-friendly, competitive and relevant to the customers. The backbone of this process is to understand the 
behavior of the customers, their needs and motivations. Customers are no more considered as receivers of the values, products, and/or services provided by these firms, rather, customers are active partners in the production process (Bettencourt 1997, Wind and Rangaswamy 2000, Pralahad and Ramaswamy 2000, Bendapudi and Leone 2003). For over a decade, researchers have advocated that organizations view service customers as "partial" employees (e.g. Bowen, 1986; Mills and Morris, 1986; Mills, Chase and Margulies, 1983).

This research reveals that in designing service products $53 \%$ of the customers are involved through feedback while, 32\% customers are involved in decision making through queries, $7 \%$ involvement is from telephonic interviews and rest $8 \%$ are not sure about it (Table-4). Customer motivation to be involved in service innovation basically stems from customer perception that their participation is needed to develop high quality services. Customers have already invested considerable energy in a service relationship; they should be more inclined to cooperate with this service provider in innovation activities.

Another role that customers can play in services delivery is that of contributor to their own satisfaction and the ultimate quality of the services they receive. Customers may not care that they have increased the productivity of the organization through their participation, but they probably do care a great deal about whether their needs are fulfilled. Table 5 reflects that in total $88 \%$ respondents believe that the views and opinions of their customers are taken into consideration in their service delivery.

Effective customer participation can increase the likelihood that needs are met and that the benefits the customer is seeking are actually attained. This is particularly apparent for services such as health care, education, personal fitness, weight loss, and others where the service outcome is highly dependent on customer participation. In these cases, the customer is an integral part of the service and unless he/she performs his/her role effectively, the desired service outcome is not possible when customers are not co-producing the service with the service supplier, their involvement in service development needs to be organized separately from the service production process. By engaging in the service process the customer acquires knowledge and skills that are important for future service development with the service provider. Such abilities include: 1. communication skills (communication of needs, expectations, own resources), 2. Understanding of the service role in customer's own processes, 3.Ability to perform an effective customer role in the service process, 4.Experience with 'technical' aspects of the service particularly in a co-performer or co-creator role in service production, 5. teamwork capabilities, 6. appropriate knowledge transfer practices, 7. trustful relations with the service provider. All these factors should facilitate customer participation in, and enhance customer potential in future service development with the service provider.

Table 6 reflects that $67 \%$ of service providers believe that they offer full service to their customers, $23 \%$ of respondents somewhat agree with this statement and rest are disagree.

A complaint is an "expression of dissatisfaction made to an organization, related to its products, or the complaints handling process itself, where a response or resolution is explicitly or implicitly expected". Effective complaint handling is fundamental to the provision of a quality service. It is an important part of the activities of any customer-facing organization. Despite quality controls and care in services delivery, negative customer experiences inevitably occur and must then be handled. The research reveals that $46 \%$ of the service providers establishes a formal process for handling customers complaints, 19\% handles their complaints through frontline staff, and rest 33\% resolves their complaint when need arises (Table 7). That means the organizations are more accessible and responsive to the complaints. A well planned and well executed complaints handling process delivers benefits in at least four areas: Customer satisfaction and retention; Organizational learning for product, services and processes improvement; Improvement to revenue and/or cost structures; and Enhanced experience for staff and customers.

'The days are gone when you can ignore complaints. Often people only want to be heard.' Dr Ferguson, Principal Partner, Brooke Street Medical Centre. Now a day resolving the complaints on time is life blood of any company. According to the present research $51 \%$ of service providers resolves customers complaint within 12 hours, $32 \%$ take time span of $12-24$ hours, $6 \%$ respondents take a time span minimum 48 hours, and rest $11 \%$ take more than 72 hours (Table 8).

Service companies dearly gain if they can do more business with existing customers for a longer period of time. Equally important, customers gain if they can establish a relationship with a competent, dependable provider of a high-risk service that presents a complex decision with regard to purchase and is difficult to evaluate. A customer fortunate enough to have an excellent auto repair person, physician, or real estate agent has a lower effort and risk burden than someone who needs the service but hasn't yet developed a satisfactory relationship. The question is what role should pricing play in RM? An obvious approach is to use price reductions to initiate relationships. That approach is easy to implement and has considerable intuitive appeal, but it is also the most easily imitated -- which is why relationships based solely on price incentives disappear so swiftly. Services marketers can develop creative pricing strategies that contribute to sustainable relationships. Such strategies offer an incentive for customers to consolidate more of their purchasing with the company and to resist the entreaties of competitors. Marketers first need to understand their customers' needs and their 
motivations for developing a long-term relationship with the company. They should also analyze potential competitors' moves and implications for profitability.

Customers don't buy products or services. They buy good feelings and solutions to problems. Most customer needs are emotional rather than logical. The more you know your customers, the better you become at anticipating their needs. Communicate regularly so that you are aware of problems or upcoming needs. Present research shows that $56 \%$ of the service providers identify the needs of the customers through complaints lodged by them, 36\% identify their needs through personal queries and rest $8 \%$ through failure of service products (Table 10). In order to identify customer needs and make use of this information you will need to do three things: $\cdots \cdot \cdots \cdot \cdot \cdot$

1. Communicate with your customers and find out how you can satisfy their needs better.

2. Establish ways to record and interpret customer feedback.

3. Use this information when making important decisions about marketing, buying, merchandising and selling. Promotion is direct way an organization tries to reach its public. This is performed through the five elements of promotion mix i.e. advertising, sales promotion, personal selling, public relations and direct marketing. The present research shows that personal interaction is the main strategy used for promotion of service products. It reveals that $23 \%$ of the service providers use $\mathrm{T} \mathrm{V}$ and radio advertising as a promotional tool, while $47 \%$ uses personal interaction, $23 \%$ uses e-mail, and rest $7 \%$ uses posters and bill boards (Table 11).

Service customization is a viable instrument for RM. Its efficacy depends on customer satisfaction and customer trust. Customization increases perceived service quality, customer satisfaction, customer trust, and ultimately customer loyalty toward a service provider. Customization has both direct and mediated effects on customer loyalty and interacts with the effects of customer satisfaction and customer trust on loyalty. According to this research $57 \%$ of the Service providers are using service customization as an effective instrument for achieving not only higher customer satisfaction, but also higher customer loyalty (Table 12). Service customization is most effective for companies that have deficits in satisfying their customers, while at the same time their customer relationships are characterized by a high level of trust. These results help managers to decide upon resource allocation to enhance customer satisfaction, trust and loyalty.

The promotional activities of an organization continue long after customer acquisition. According to the research 74\% service providers incorporate communication tactics that are effective in reminding current customers why they should continue purchasing a brand's products is just as important as promoting to potential customers (Table 13). As more brands compete for consumer attention in an increasingly crowded marketplace, organizations must develop marketing communications strategies that address customer challenges, appeal to customer needs, and drive repeat sales.

Former customers are the best source for future sales, even in businesses where customers make purchases only every few years. After all, satisfied customers talk to others, so they're an important referral source. Remember, "word of mouth" advertising doesn't just happen; it has to be nurtured.Even if they don't need your product or service again immediately, satisfied customers talk to others, so they're vital for getting referrals. If you want to build word-of-mouth business, it's your former (and current) customers whose mouth the words are going to come from.

Customer satisfaction is defined as a result of customer's evaluation to the consumption experience with the services. As per the research $86 \%$ of the service businesses are trying their best to improve their service quality in order to make customers satisfied with their services (Table 15).

\section{Conclusion}

From the research conducted it has been observed that relationship marketing and service delivery are the factors responsible for the performance and the growth of service companies. Relationship marketing is the key to business success, specifically in service industry. Now a day, companies are putting more emphasis on customer care and long-term relationship than on anything else. It takes a lifetime to build and maintain a strong, reliable, trustworthy relationship but needs only moments to shatter everything down. It is a fragile bondage with the customers with whom marketers usually don't have any blood relation yet it is the crucial most things for the survival and growth of businesses. To conclude, beyond doubts RM is a paradigm in marketing literature, eventhough it is a new but old concept. But the conceptual bases of RM are not yet completely developed even after two decades of existence. The future survival and its status depend on development of a solid theoretical framework based on empirical research. It plays a major role in service performance and customer retention. The managerial implications of these findings include a commitment to the implementation of CRM within the organization as well as a commitment to the provision of excellent customer service in order to affect the relationship building and the implementation of CRM. This places great emphasis on improving the customer service of personnel in order to ensure that the objectives of the CRM strategy are attained.Finally, to conclude it all, future research is still needed to justify and strengthen the outcomes of this research. There may have been research similar to this topic but the situations in all the researches may be 
different, including this research. A slight change in the research context could bring about changes in findings. Therefore, future researchers are welcomed to conduct a similar research as this in the same context.

\section{Suggestions for further research}

In addition to the suggestions put forth in the discussion above, there is a general need for more research on RM strategies and their actual effects on customer relationship strength. However, more effort should also be given to studying customers' desire, or lack of it, for maintaining close customer relationships with service providers. Too little is still known regarding the nature of customer relationships, what modern customers expect from their service provider relationships, what forms these relationships take, and how they differ between profitability segments. These strategies aim at increasing customers' commitment to the service provider and, thereby, increasing their share-of-wallet through cross-selling activities. In addition, more in-depth studies are needed to understand differences between service provider and customer views of relationships, and to gain better knowledge of how front-line employees cope with having to develop different types of relationships with different customer groups.Specific actions that can be considered by management include:

- Customer service levels are critical in establishing and developing relationships.

- Training with respect to customer service and improvement in the service levels offered by staff.

- In any implementation, it is necessary to identify, differentiate and then interact withcustomers in order to provide customized service.

- Continuous interaction with the customers is necessary

In this study the main antecedents of switching behavior that came in to light be customer satisfaction, relationship of service provider and customer in terms of duration and service feedback. As such, highly satisfied customers tend to demonstrate a high likelihood of repurchase and higher tolerance to price increases by providers or price decreases by competitors. A negative link between satisfaction and customer complaints shows that the more satisfied a customer is, the less he or she is prone to complain.

It is imperative to develop an overall approach to managing customers. There is a need to link back to the overall corporate and marketing strategy of the company. This link is important as significant investment and changes in many policy areas, processes and structures are required in developing the relationship marketing capability and a link back to corporate strategy may be important to justify the investment to senior management of service companies. There is a need for detailed data identification, collection, analysis and interpretation of customer information to enable the detailed strategy to be implemented with confidence in the service sector.If RM is to be implemented successfully in the Service Sector then there is the necessity of developing the processes, media, systems and organisational infrastructure (organisation, staff recruitment and training) to support relationship marketing.

\section{References:}

[1]. "The increasing focus on Managing Relationships and customer retention", The journal of Language, Technology and Entrepreneurship in Africa, vol.2 No.1 2010,ISSN- 1998-1279.

[2]. Aminu S.A, "Empirical Investigation of the effect of RM on Banks customer loyalty in Nigeria", IJCRB, Vol.4, No.6, Oct 2012.

[3]. Berndt Adele, Herbstfrikkie and Roux Lindie, "Implementing a customer relationship management programme in an emerging market”, Journal of global business and technology, Vol.1, No.2, Fall 2005.

[4]. BojeiJamil\&Radam Alias, Abu Mimiliana, "The underlying dimensions of RM in the Malaysian Mobile service sector", $3{ }^{\text {rd }}$ International Conference on Business and Economic Research (3 ${ }^{\text {rd }}$ ICBER 2012) Proceedings, 12-13 March 2012, ISBN- 978-9675705-05-2.

[5]. Chung Yi-Chan, TienShiaw-Wen, Hung Chih\& Tsai, Tang Lin-Lin, “ An Empirical study of CRM Implementation in Taiwan's Machine industry", Journal of business and public affairs, Vol.1, Issue 12007, ISSN-1934-7219.

[6]. GautamPriyanka, \&Chandhok Dr. Anil, "Swithching behavior of subscribers in Indian Telecom sector", IJRFM, Vol.1, issue 3 (July, 2011) ISSN- 2231-5985.

[7]. Gupta Ashish, sahu G.P., "A literature review and classification of relationship marketing research", International journal of customer relationship marketing and management, 3(1), 56-81, Jan- March 2012

[8]. Joshi Dr. Sandhya, KhuranaParveen\&KhuranaShashi, "Service quality in Telecom sector- A study of Telecom service providers of Chandigarh", IJMMR, Vol.1 Issue1 (Dec, 2010), ISSN-2229-6883

[9]. Kakani Ram kumar\&Sridev R., "Telecom sector-achieving Sustainable Corporate growth, IIMC, WPS No 328 , Feb 1998.

[10]. Krishna M.Sharma, "Study of customer satisfaction on services provided by modern trade in Pune City", Vol.1 spectrum e-journal, Feb 2010, ISSN-0973-1513.

[11]. Leverin Andreas \&Liljander Veronica, “ Does customer relationship marketing improve customer relationship satisfaction and loyalty?"

[12]. Mary Jo Bitner, William T. Faranda, Amy R. Hubbert, Valarie A Zeithaml, " Customer contributions and roles in service delivery”, International Journal of service industry Management, Vol. 8 No 3, 1997, pp 193-205, MCB University Press, ISSN0956-4233

[13]. MukhiddinJumaev, Prof. Dr. Dileep Kumar. M, Jalal R.M. Hanaysha, “impact of RM on customer loyalty in the Banking Sector”, Far east journal of psychology and business, Vol.6, No.3, March 2012.

[14]. ParvatiyarAtul, ShethJagdish N, "CRM: Emerging practice, process and discipline", Journal of economic and social research 3(2) 2001, 1-34. 
[15]. Pisal, Dr. P.K, "Practical Emotional Touch for framing customer service strategies", Vol. 1 Spectrum e-journal, Feb 2010, ISSN0973-1513.

[16]. RamnarainTaruna, \&GungaphulMridula, "The importance of RM in services: The small business sector in Mauritius", International research symposium in service management, 24-27 Aug, 2010, ISSN- 1694-0938.

[17]. Reichheld, F.F. (1996), The Loyalty Effect: The Hidden Force Behind Growth, Profits and Lasting Value, Harvard Business School Press, Boston, MA.

[18]. Reichheld, F.F. and Sasser, W.E. (1990), "Zero defections: quality comes to services,” Harvard Business Review, Vol. 68, No. 9/10, pp. 105-11

[19]. Ruard Sabine Flambard, "Relationship Marketing in Emerging Economies: Some lessons for the future", Vikalpa, Vol.30, No.3, July-Sep 2005.

[20]. Shaker T. Ismail, "The effect of RM on the Organizational outcomes; An applied study in Jordanian Insurance Companies", European journal of social sciences, Vol.12, No.2 2009.

[21]. Sheth, J.N. and Parvatiyar, A. (1995), "The evolution of relationship marketing”, International Business Review, Vol. 4 No. 4 , pp. $397-418$.

[22]. Silva K.A and Yapa S.T.W.S, "Customer retention: With special reference to Telecommunication Industry in Srilanka”, Paper presented at International conference on Business and Information, July 2009, Kuala Lumpur, Malaysia.

[23]. Valarie A. Zeithaml, A. Parasuraman, Leonard L. Berry, "Problems and strategies in Services Marketing", Journal of Marketing, Vol.49 (spring-1985), 33-46.

[24]. VanikamathMs, Bhonsale Ms. Shweta, \&Manjrekar Dr. Pradip, “ CRM: A key success factor in services marketing (A Case study of Tourism (Hotel) services in navi Mumbai)", conference on tourism in India-Challenges ahead, 15-17 May 2008, IIMK.

Table: 1 Profile of the respondents

\begin{tabular}{|c|c|c|c|}
\hline S.No & & Frequency & Percentage \\
\hline (A) & Age group & & \\
\hline 1 & $25 \&$ below & 11 & 11 \\
\hline 2 & $26-35$ & 55 & 55 \\
\hline 3 & $36-45$ & 26 & 26 \\
\hline 4 & $46 \&$ above & 8 & 8 \\
\hline (B) & Gender & & \\
\hline 1 & Male & 68 & 68 \\
\hline 2 & Female & 32 & 32 \\
\hline (C) & Education & & \\
\hline 1 & Senior Secondary & 3 & 3 \\
\hline 2 & Graduate & 38 & 38 \\
\hline 3 & Post Graduate & 33 & 33 \\
\hline 4 & Professional Qualification & 26 & 26 \\
\hline (D) & Service tenure & & \\
\hline 1 & Less than 6 months & 3 & 3 \\
\hline 2 & 6 months-1year & 4 & 4 \\
\hline 3 & 1 year-4years & 12 & 12 \\
\hline 4 & 4 years \& above & 81 & 81 \\
\hline (E) & Service Industry & & \\
\hline 1 & Telecom & 44 & 44 \\
\hline 2 & Banking & 6 & 6 \\
\hline 3 & Insurance Education & 8 & 8 \\
\hline 4 & Tourism & 10 & 10 \\
\hline 5 & Education & 7 & 7 \\
\hline 6 & Entertainment & 2 & 2 \\
\hline 7 & Healthcare & 18 & 18 \\
\hline 8 & Real Estate & 2 & 2 \\
\hline 9 & Others & 3 & 3 \\
\hline
\end{tabular}

Table: 2 Role of RM in the service sector

\begin{tabular}{|c|l|c|c|}
\hline S.No & \multicolumn{1}{|c|}{ Role of RM in Service Performance } & Frequency & 27 \\
\hline 1 & Very crucial & 57 & 27 \\
\hline 2 & Important & 57 & 10 \\
\hline 3 & Insignificant & 6 & 10 \\
\hline 4 & Not Certain & 100 & 6 \\
\hline & Total & 100 & \\
\hline
\end{tabular}

Table: 3 Knowing the Customers

\begin{tabular}{|c|l|c|c|}
\hline S.No & \multicolumn{1}{|c|}{ Customer Information } & Frequency & Percentage \\
\hline 1 & Very Well & 43 & 43 \\
\hline 2 & Moderately well & 39 & 39 \\
\hline 3 & Transaction based & 15 & 15 \\
\hline 4 & Unfamiliar with Customer information & 3 & 3 \\
\hline & Total & 100 & 100 \\
\hline
\end{tabular}

Table: 4 Customers involvement in decision making when designing service products

\begin{tabular}{|l|l|l|r|}
\hline S.No & Customers Involvement for designing service products & Frequency & Percentage \\
\hline
\end{tabular}


Impact Of Relationship Marketing On The Performance Of Service Companies: An Empirical Study

\begin{tabular}{|c|l|c|c|}
\hline 1 & Through Feedback & 53 & 53 \\
\hline 2 & Through customer queries & 32 & 32 \\
\hline 3 & Through Telephonic interviews & 7 & 7 \\
\hline 4 & Not sure & 8 & 8 \\
\hline & Total & 100 & 100 \\
\hline
\end{tabular}

Table: 5 Customers Involvement in Service Delivery

\begin{tabular}{|c|l|c|c|}
\hline S.No & \multicolumn{1}{|c|}{ Customers Involvement in Service delivery } & Frequency & Percentage \\
\hline 1 & Most Definitely & 39 & 39 \\
\hline 2 & Definitely & 49 & 49 \\
\hline 3 & Not Necessarily & 9 & 9 \\
\hline 4 & Not sure & 3 & 3 \\
\hline & Total & 100 & 100 \\
\hline
\end{tabular}

Table 6: Service offering from service providers

\begin{tabular}{|c|l|c|c|}
\hline S.No & \multicolumn{1}{|c|}{ Service offering from Service Providers } & Frequency & Percentage \\
\hline 1 & Agree & 67 & 67 \\
\hline 2 & Disagree & 6 & 6 \\
\hline 3 & Somewhat Agree & 23 & 23 \\
\hline 4 & Somewhat disagree & 2 & 2 \\
\hline 5 & Don't Know & 2 & 2 \\
\hline & Total & 100 & 100 \\
\hline
\end{tabular}

Table: 7 Complaint Handling Process

\begin{tabular}{|c|l|c|c|}
\hline S.No & \multicolumn{1}{|c|}{ Complaint Handling process } & Frequency & Percentage \\
\hline 1 & Through formal process & 46 & 46 \\
\hline 2 & Through frontline staff & 19 & 19 \\
\hline 3 & As per requirement & 33 & 33 \\
\hline 4 & No Process & 2 & 2 \\
\hline & Total & 100 & 100 \\
\hline
\end{tabular}

Table: 8 Complaint Handling Duration

\begin{tabular}{|c|l|c|c|}
\hline S.No & \multicolumn{1}{|c|}{ Complaint Handling duration } & Frequency & Percentage \\
\hline 1 & Less than 12 hours & 51 & 51 \\
\hline 2 & Between 12-24 hours & 32 & 32 \\
\hline 3 & After 48 hours & 6 & 6 \\
\hline 4 & After 72 hours & 11 & 11 \\
\hline & Total & 100 & 100 \\
\hline
\end{tabular}

\begin{tabular}{|c|l|c|c|}
\hline \multicolumn{3}{|c|}{ Table: 9 Reduced price offerings to existing customers } \\
\hline S.No & \multicolumn{1}{|c|}{ Price reduction offerings } & Frequency & Percentage \\
\hline 1 & Agree & 48 & 48 \\
\hline 2 & Disagree & 9 & 9 \\
\hline 3 & Somewhat agree & 31 & 31 \\
\hline 4 & Somewhat Disagree & 0 & 0 \\
\hline 5 & Don't know & 12 & 12 \\
\hline & Total & 100 & 100 \\
\hline
\end{tabular}

\begin{tabular}{|c|l|c|c|}
\hline \multicolumn{1}{|c|}{ Table: 10 Identifying Customer needs } \\
\hline S.No & \multicolumn{1}{|c|}{ Identifying customer needs } & Frequency & Percentage \\
\hline 1 & Through complaints lodged by customers & 56 & 56 \\
\hline 2 & Through personal queries & 36 & 36 \\
\hline 3 & Through failure of service products & 8 & 8 \\
\hline 4 & Others & 0 & 0 \\
\hline & Total & 100 & 100 \\
\hline
\end{tabular}

\begin{tabular}{|c|l|c|c|}
\hline \multicolumn{3}{|c|}{ Table: 11 Sales and Promotion strategies } \\
\hline S.No & \multicolumn{1}{|c|}{ Sales and promotion strategy } & Frequency & Percentage \\
\hline 1 & TV and Radio advertising & 23 & 23 \\
\hline 2 & E-mail & 23 & 23 \\
\hline 3 & Personal Interaction & 47 & 47 \\
\hline 4 & Posters and bill boards & 7 & 7 \\
\hline & Total & 100 & 100 \\
\hline
\end{tabular}

Table: 12 Possibility of customization of services 
Impact Of Relationship Marketing On The Performance Of Service Companies: An Empirical Study

\begin{tabular}{|c|l|c|c|}
\hline S.No & \multicolumn{1}{|c|}{ Possibility of Customization of services } & Frequency & Percentage \\
\hline 1 & Agree & 57 & 57 \\
\hline 2 & Disagree & 11 & 11 \\
\hline 3 & Somewhat agree & 22 & 22 \\
\hline 4 & Somewhat disagree & 4 & 4 \\
\hline 5 & Don't Know & 6 & 6 \\
\hline & Total & 100 & 100 \\
\hline
\end{tabular}

Table: 13 Reminding future services to customers

\begin{tabular}{|c|l|c|c|}
\hline S.No & \multicolumn{1}{|c|}{ Reminding future services to customers } & Frequency & Percentage \\
\hline 1 & Agree & 74 & 74 \\
\hline 2 & Disagree & 3 & 3 \\
\hline 3 & Somewhat agree & 17 & 17 \\
\hline 4 & Somewhat disagree & 0 & 0 \\
\hline 5 & Don't know & 6 & 6 \\
\hline & Total & 100 & 100 \\
\hline
\end{tabular}

Table: 14 Contacting Former customers

\begin{tabular}{|c|l|c|c|}
\hline S.No & \multicolumn{1}{|c|}{ Contacting former customers } & Frequency & Percentage \\
\hline 1 & Agree & 54 & 54 \\
\hline 2 & Disagree & 6 & 6 \\
\hline 3 & Somewhat agree & 25 & 25 \\
\hline 4 & Somewhat disagree & 4 & 4 \\
\hline 5 & Don't know & 11 & 11 \\
\hline & Total & 100 & 100 \\
\hline
\end{tabular}

Table: 15 Customers satisfaction as a top most priority

\begin{tabular}{|c|l|c|c|}
\hline S.No & \multicolumn{1}{|c|}{ Customer satisfaction as a top most priority } & Frequency & Percentage \\
\hline 1 & Agree & 86 & 86 \\
\hline 2 & Disagree & 6 & 6 \\
\hline 3 & Somewhat agree & 7 & 7 \\
\hline 4 & Somewhat disagree & 1 & 1 \\
\hline 5 & Don't know & 0 & 0 \\
\hline & Total & 100 & 100 \\
\hline
\end{tabular}

